that had elapsed since the last examination the stone had evidently increased greatly in size, for when $I$ saw him the sound came in contact with a stone immediately it entered the bladder and could not easily be passed around and beyond it. With the finger in the rectum a large calculus could be felt directly above the prostate, and its size and shape were roughly ascertained. By using the sound in the bladder in conjunction with the examination per rectum the more important information was gained that the stone was firmly fixed in the floor of the bladder, for it could not be rolled over or moved from its position in relation to the prostate by uressure either from the finger behind or from the sound in front.

Under the circumstances it was clear that the only way of removing the stone was by the suprapubic operation, and this the patient had no hesitation in submitting to for his sufferings were undoubtedly very great. I performed the operation a few days later at the Cowra District Hospital and removed a calculus weighing a trifle over four and a quarter ounces. The stone (which I still have in my possession) is egg-shaped with flattened anterior and posterior surfaces, and is rather bigger than a duck's egg, measuring eight inches in its largest circumierence. appears to be composed of uric acid with a slight deposit of phosphates. About two-thirds of the length of the stone projected into the cavity of the bladder, but its larger end was tightly held in a sacculus behind the prostate. and it was only after enlarging the incision in the bladder sufficiently to introduce the fingers of both hands that I could disengage the stone, the constricting edges of the sac having formed two deep lateral grooves in the calculus.

The operation was in all other respects carried out in the usual way, and the patient, notwithstanding his age, made a rapid recovery, returning to the diggings five weeks after the operation. When I last heard of him several months later he had had no further tronble. I have been told by practitioners of long Australian experience that cases of stone are exceedingly uncommon in that country. I do not know whether that opinion is confirmed by statistics.

I am, Sirs, yours faithfully,

RALPH C. BARTLET, M.R.C.S. Eng., L.R.C.P. Lond. Romsey, Hants, Dec. 21st, 1901.

\section{THE BOYCOTT OF CONSUMPTIVES AT MENTONE.}

\section{To the Editors of THE LANCET.}

SiRs, - The recent semi-official edict of the hotel proprietors at Mentone, in the Continental Bradshaw, intimating that persons suffering from consumption would not be received as guests, has created some excitement in the Riviera and many consider this virtual boycott of invalids as an unjustifably harsh measure. This attitude of the leading hotel proprietors of Mentone is no new thing, however, though it has not before been so uncompromisingly expressed. It must be remembered that the character of Mentone as a winter resort has materially changed in the last 20 years or so. The history of Mentone, so far as foreigners are concerned, may be divided into three distinct phases. For many years after the late Dr. J. H. Bennett (the tutelary genius of Mentone) "invented" and made Mentone it was regarded as an invalid resort pure and simple, and in the case of consumptive patients ordered to winter abroad the choice of the faculty was practically limited to Mentone or Madeira. Its great vogue as the Meca of the consumptive gave the place a distinctly funereal reputation, and it was erroneously supposed that the town was simply a consumptive preserve. Everyone remembers Mark 'Twain's witticism that but for an occasional funeral there would be no life in the place, while the famous French romancer, M. Guy de Maupassant, had much to do with the perpetuation of the "Cave of Despair" legend when he wrote: "This charming and balmy country is the hospital of society and the lowery cemetery of aristocratic Europe. How truly in every part of the world this lovely and terrible spot must be accursed, this ante-room of death, perfumed and sweet, where so many humble and royal families, burghers or princes, have left someone, some child on whom they concentrated all their hopes and lavished all their love and tenderness." Then came the second stage in Mentone's history, when it became a quiet and retired resort, much frequented by non-invalid visitors who objected to the expense of ultra-fashionable Cannes and the gaiety and bustle of Nice, the metropolis of the Riviera. For many years, too, it was the favourite resort of overworked clergy attracted by the combination of cheap living and lovely scenery

Of late years a still more marked change has taken place. Mentone has become distinctly fashionable and consequently almost as expensive a residence as Nice or San Remo, though less so than Cannes or Monte Carlo. Then its proximity to the latter place has made it popular with many frequenters of the cusino who for obvious reasons prefer not to live actually under the shadow of the palace of fortune. There is no doubt something to be said for the hotel proprietors' point of view. The opinion, whether erroneous or not, now gaining ground, that Mentone is more or less a consumptive settlement would be obviously prejudicial to the interests of Mentone in general as a residential winter resort and to the hotel-keepers in particular. As a preliminary measure steps were taken to convince the public that this beauty-spot of the Riviera was not exclusively to be regarded as a Mecca for invalids. Finally, and within recent years, those interested in the hotel enterprise let it be understood that, taking a leaf out of the book of the Pontresina hotel managers (who have for many years tabooed phthisical visitors), no consumptive person would be admitted.

It must be remembered that Mentone is practically one great hotel-there are more hotels in comparison to the population than at any town in the Riviera, except Cannes and Monte Carlo. Hotel-keepers must live, and it is unquestionable that ordinary visitors will not patronise an hotel which is known to take guests suffering from consumption. Thus, to put it bluntly, as there are not enough invalids to go round, the bold alternative of mainly depending upon a consumptive clientète as at Davos is impracticable.-I am, Sirs, yours faithfully,

Dec. 19th, 1901. E. A. REYnolds-BaLL,

Author of "Mediterranean Winter Resorts."

\section{WET DAYS.}

\section{To the Editors of THE LANCET.}

SIRS,-May I invite your attention to some weather facts which, I think, are not without their medical bearings? In the rough diagram herewith each dot represents a day with $0.4 \mathrm{in}$. of rainfall or more at Greenwich; and the diagram

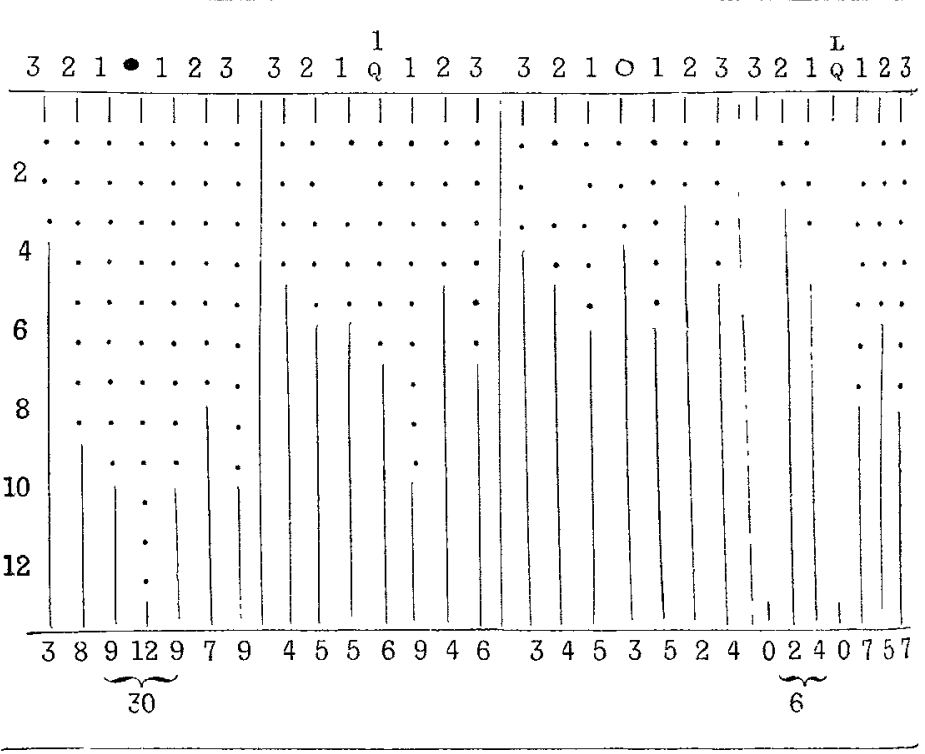

Shows the distribution of such days (in the last 12 years, 18891900) in the week about new moon, first quarter, full moon, and last quarter respectively. Please note the following: (1) the preponderance about new moon at once strikes the eye; (2) the third day berore last quarter and the day of last quarter were without cases of such rainfall ; (3) while the three-day group before last quarter, and that ending with last quarter, had each six cases the three days about new moon had 30 (i.e., five times as many); and (4) it might be shown that the total number of such days in weeks about new moon is greater than in weeks about last quarter in every year of the 12 except two, when the numbers were equal. Whether these facts point to lunar influence or not 